\title{
Irak-Duhok'ta Petrol İstasyonların Çalışan İşçilerinin Mikronükleus Frekansı Üzerine Benzenin Etkisi
}

\section{The Effects of Benzene on Micronuclei Frequency of Workers in Petrol Stations in Duhok- Iraq}

\author{
${ }^{1}$ Dian J. SALIH, ${ }^{2}$ Marwan KH. QADER, ${ }^{3}$ Mosher R. AHMED \\ ${ }^{1}$ Department of Anatomy, College of Medicine/ University of Duhok, Iraq \\ ${ }^{2}$ Department of Medical Analysis, Cihan University, Iraq \\ ${ }^{3}$ Department of Environment, College of sciences/ University of Zakho, Iraq
}

Dian J. SALIH : https://orcid.org/0000-0003-1006-086X

Marwan KH. QADER : https://orcid.org/0000-0001-7612-4358

Mosher R. AHMED : https://orcid.org/0000-0001-9021-5379

\section{Öz}

Amaç: Benzen başlıca organik ürünlerden biridir, bu organik ürüne kronik maruz kalan insanlar çeşitli sağlık sorunlarına maruz kalmaktadır. Bu çalışmanın amacı, Duhok eyaletindeki benzin istasyonu çalışanları arasında mesleki benzene maruz kalma ile ilişkili mikronükleus sıklığını değerlendirmektir.

Materyal ve Metot: Çalıșma gruplarına mesleki olarak maruz kalan 25 benzin istasyonu çalışanı dahil edildi ve aynı sayıda yaş olarak eşleştirilmiş kontrol alındı ve genetik hasar açısından değerlendirildi. Pul pul dökülmüş Buccal hücreleri her iki gruptan steril firça kullanılarak toplandı. Etanol içinde sabitlenen ve Giemsa boyası ve 1000 hücre ile boyanmış lamlar bir ışık mikroskobu altında incelenmiștir. Student $t$ - testi ve $P<0,05$ ile yapılan veri yorumlaması için istatistiksel analiz istatistiksel olarak anlamlı kabul edildi. Bu çalışmada sigara ve alko öyküsü olan hem kontrol hem de çalışanlar çalışma dışı bırakılmıștır.

Bulgular: Kontrol deneklerine kiyasla benzene maruz kalan işçilerde anlamlı düzeyde yüksek mikronükleus frekansi bulundu (sirasiyla 4,65 \pm 2 ve $1,22 \pm 7$ ). Maruz kalma süresi mikronükleus frekansı üzerinde de anlaml etkiler gösterirken $(\mathrm{P}<0,05)$, yaşın etkisi anlamlı değildi $(\mathrm{P}>0,05)$.

Sonuçlar: Çalışmamızın sonuçları, benzenin maruz kalan deneklerde mikronükleus sıklığını arttırma potansiyeline sahip olduğu sonucuna varmıştır.

Anahtar Kelimeler: Benzen, kanserojen, mikronükleus sıklığı, toksik ajanlar

\section{ABSTRACT}

Objective: Benzene is one of the major organic product, people with chronic exposure to this organic product are exposed to several health problems. The aim of this study was to evaluate the micronuclei frequency associated with occupational exposure to benzene among petrol station workers in Duhok Province.

Materials and Methods: The study groups included twenty-five occupationally exposed petrol station workers and twenty five age matched controls were recruited and evaluated for genetic damage. Exfoliated Buccal cells were collected from both groups by using the sterile brush. Slides fixed in ethanol and stained with Giemsa stain and 1000 cells were studied by using a light microscope. Statistical analysis for data interpretation performed by Student's $\mathrm{t}$-test, and $\mathrm{P}<0.05$ was considered statistically significant. In this study, both Control and workers with history of Tobacco smoking and alcohol were excluded.

Results: As compared to control subjects, significant high level of micronuclei frequency was found in the workers exposed to benzene ( $4.65 \pm 2$ and $1.22 \pm 7$ respectively). Period of exposure also showed considerable effects $(\mathrm{P}<0.05)$ on micronuclei frequency, while effect of age was non-significant $(\mathrm{P}>0.05)$.

Conclusions: The results of our study concluded that benzene have the potential to increase micronuclei frequency in the exposed subjects.

Keywords: Benzene, carcinogenic, micronuclei frequency, toxic agents
Sorumlu Yazar / Corresponding Author:

Dian Jamel Salih

Swaro 151, Duhok/ Iraq

Telephone: 009647504568201

E-mail address: dian.jamel@uod.ac
Yayın Bilgisi / Article Info:

Gönderi Tarihi/ Received:17/07/2019

Kabul Tarihi/ Accepted: 11/04/2020

Online Yayın Tarihi/ Published: 30/06/2020 


\section{INTRODUCTION}

Petrol is a mixture of saturated and unsaturated hydrocarbons that mostly used for internal combustion engines. Its fuel contains approximately $7 \%$ alkenes, $62 \%$ alkanes and $31 \%$ aromatics and additives. Generally, it contains more than 150 chemicals, including small amounts of benzene and tetraethyl lead. ${ }^{1,2}$ The carcinogenicity or genotoxicity of some components of petrol such as manganese, toluene and ethylene, have not been proven, while benzene is wellestablished and classified as a Group one human carcinogen. Exposure to gasoline vapors is classified by the International Agency for Research on Cancer (IARC) as possibly carcinogenic to humans, mainly on the basis of carcinogenicity of some components, such as benzene. ${ }^{3}$

Prolonged occupational exposure of workers to petroleum and its derivatives especially by absorption through the skin or through inhalation of petroleum fumes during refueling is hazardous and lead to several health problems, due to its acute and chronic effects. ${ }^{4}$

Exposure to high levels of Benzene even for short duration can lead to headaches, dizziness, drowsiness, confusion and unconsciousness. While continuous and long term exposures of benzene cause bone marrow not to produce enough red blood cells which can lead to anemia, damage the immune system by changing blood levels of antibodies. ${ }^{5,6}$

Benzene metabolizes to give ring, hydroxylated and ring-opened metabolites with genotoxic properties such as aneugenicity and clastogenicity. In spite of several numbers of studies on genotoxicity of benzene, the study of leukemogenic activity at realistic exposure levels is of immediate concern. ${ }^{7}$

Several studies suggested that chronic exposure to benzene causes acute myeloid leukemia, myelodysplastic syndrome and other hematologic malignancies such as non-Hodgkin's lymphoma and leukemia in children as well as lymphoproliferative disorders. It also may contribute to the risk of DNA damage. ${ }^{8}$

Workers exposed to high levels of benzene for a long period of time showed genotoxicity with an increase in micronuclei frequency, sister chromatid exchanges and breaks of DNA strands. There are also several other chromosomal aberrations found in lymphocytes of exposed workers to Benzene, such as gaps, breaks, and sister chromatid exchanges. ${ }^{9,10,11}$

There are many studies have been conducted to evaluate the genotoxic and cytotoxic effects of Ben- zene, but there are few studies excluded all other factors. This study aims to evaluate the cytogenetic damage in exfoliated buccal cells taken from petrol station workers and control subjects with no tobacco habit, alcohol consumption using the micronucleus assay.

\section{MATERIALS AND METHODS}

This study was started after the approval of the Duhok Medical Scientific and Ethical Committee (Date: 08.01.2019 and Decision no: 62).

Sample collection: The present study was done according to the cross-sectional descriptive study design. This study carried out on 50 individuals randomly selected from different petrol stations located in Duhok- Iraq. All participants classified into two main groups. Group one: consisted of petrol station workers. Group two: consisted of randomly selected healthy individuals who were not exposed to benzene.

A questionnaire form was filled for each individual that included information regarding sex, age, medical history, marital status, duration of exposure, smoking and alcohol consumption habit and occupational history.

The petrol station workers group consisted of 25 individuals in the age group of (18-43) who were randomly selected. The control group also consisted of 25 individuals collected from rural areas and matched by age to the exposed workers without any exposure to benzene, toxic chemicals and tobacco smoking habits. Any subject with smoking habits, intake of drugs or other medication and alcohol consumption was excluded from the study.

Buccal Micronucleus Assay : Before taking a buccal cell, participants were advised to rinse their mouth with distilled water twice to remove any unwanted de-bris. A small brush was used to collect cell samples from the inner wall of the left and right cheeks. Then the brush was dipped in a tube containing normal saline. After centrifugation, the cell suspension was transferred and spread with a sterile glass slide.

For the Giemsa staining method, the slides were fixed at $90 \%$ ethanol for 10 minutes. Then, they were air-dried and stained in Giemsa, studied under a light microscope. Two slides were made from each patient. A to-tal of 1000 cells were scored per individual to determine the frequency of various cell types according to Tolbert et al. ${ }^{12}$

Statistical Analysis: All the statistical analyses were 
performed and the mean frequencies of MN cases and controls were compared using Student's t test. $\mathrm{P}<0.05$ was considered statistically significant.

Ethics approval and consent to participate: We have obtained approval to conduct our study from the ethics committee of Duhok general hospital. We have also obtained an informed verbal consent from participants to participate since it involved little risk of harm for the participants and the study was considered as part of clinical consultation. The ethics committee approved the verbal consent. We received also permission to use the patient records from the personnel keeping these records and the confidentiality and anonymity of the obtained data ensured.

\section{RESULTS}

A total of 50 male participants (25 exposed to benzene and 25 controls) were included in the current study. The age of the enrolled subjects ranged from 18 years to 43 (mean $28.3 \pm 7$ ) years.

The duration of working in the petrol station ranged from 6 months to 65 years (mean $4.1 \pm 8$ years). The daily shift hours of the exposed workers ranged from 6 to 8 hours exposure to gasoline fumes (mean $75 \pm 0$. hours) as shown in Figure 1.

The basic characteristics of the population studied of both exposed workers and controls are presented in (Table 1) included age, history of occupation and daily shift working hours.

The Micronuclei frequency was studied in 25 petrol station workers and in 25 controls. Workers showed significant induction of $\mathrm{MN}$ when compared with controls $(\mathrm{p} \leq 0.05)$.

For the petrol station workers, the range of Micronuclei frequency was $(0-14)$; the mean calculated was (4.65 \pm 2$)$. While, for the control group; the range of Micronuclei frequency was (0-6). The mean calculated was (1.22 \pm 7$)$.

The mean frequency of micronuclei in exfoliated buccal epithelial cells of petrol station workers and controls and buccal epithelial cells with micronucleus stained with Giemsa Stain shown in Figure 2 and Figure 3.

\section{DISCUSSION AND CONCLUSION}

Occupational exposure to hazardous chemicals and toxic substances for a long period of time without using any protective equipment may lead to a variety of health problems ranged from irritation to carcinogenicity. Petrol stations are a commonplace where workers, who are a part of fuelling and refueling of vehicles, are at higher risk of health effects. ${ }^{13}$
Petrol station workers are regularly exposed to volatile organic compounds such as toluene, benzene, ethylbenzene and xylene from fuel vapors during dispensing fuel, in addition to emissions from vehicle exhausts. They are directly exposed to these chemical compounds through inhalation and direct dermal contacts. ${ }^{14}$

In most cities of Iraq, petrol stations are located on main streets and workers at these stations have a higher opportunity for exposure, because most of them are engaged in petrol filling for more than eight hours a day and do not wear personal protective equipment and personal hygiene is not available in the most workplace.

In another hand, all petrol station workers in Duhok city that included in this study were males as our traditions society refused to engage females in these occupations; females themselves are not ready to perform such hard-working, exposure to risks and night shift work.

The Current research work showed a significant micronucleus frequency, as genotoxic indicators in the exposed subjects as compared to the control group (4.65 $\pm 2,1.227 \pm$ respectively); our results going with the results of Hidayat et al. (2016) research in the same object that is done in Erbil - Iraq. They showed significant increases in the number of chromosomal aberrations peripheral lymphocytes with a mean of $(52 \pm 0.32)$ in the exposed group as compared with the unexposed group with a mean of (5 \pm 0.20.$)^{6}$

This study correlates with the study done by Celik et al. in Turkey who showed a significant difference of micronucleus frequency in fifty workers of petrol stations than that in control group $(1.34 \pm 0.80$, $0.47 \pm 0.03$ respectively). ${ }^{4}$

Our results also agreed with a study from Egypt, India and Serbia ${ }^{5,711}$. A large number of studies reported a statistically significant elevation of micronuclei levels in exposed individuals compared with control groups.

Nowadays, micronuclei assay in both lymphocytes and exfoliated epithelial cells used to evaluate occurrences of chromosomal damage and their relation with cancer.

There are many chemical carcinogens present in the occupational environment and most cause structural alterations in DNA which lead to genetic damage or genomic instability in the form of chromosomal abnormalities like micronuclei, Dicentric, sister chromatid exchange chromosomal breaks and Gaps. ${ }^{15}$

Benzene also causes other chromosomal aberrations, 
mostly gaps, breaks, and sister chromatid exchanges in lymphocytes of exposed workers. These suggest that chromosome abnormalities may be the most likely mechanisms by which benzene induces genetic alterations that lead to leukemia in humans. ${ }^{16}$ There are several reports describing the effect of Age, smoking and alcohol consumption on micronuclei frequency. A study by Benites et al. reported that smoking and alcohol habits are not related to the levels of micronuclei cells in petrol station workers. Moreover, Kopjar et al. revealed that age and smoking significantly increased the values of micronuclei, while Keretetse et al. reported that age and smoking had a significant impact on the level of DNA damage in African petrol attendants. ${ }^{17,18}$

In order to exclude the possible confounding effect of smoking and alcohol consumption on the evaluation of occupational exposure to benzene, in present study workers and controls with a history of smoking and alcohol habits exclude and this was a great difficulty faced us during sample collection, because of most workers were smokers or Shisha consumers. The health effects of working with petrol on a daily basis can be minimized if the chemicals making the petrol composition are within occupational exposure limits, and appropriate health and safety practices are adhered to.

In conclusion, a higher frequency of micronuclei was observed in petrol station workers when exposed for a longer duration of time but no statistical significance observed with increasing age. Therefore, it's necessary to inform petrol station workers about the hazardous and genotoxic effects of benzene when exposed for a long time and advise them to wear an Earloop face mask. Regular health checkups should be conducted for petrol pump workers to reduce the risk, because the assessment of micronuclei frequency can be used as a biomarker for early detection of cancer.

Ethics: This study started after the approval of the Duhok Medical Scientific and Ethical Committee (Date: 08.01.2019, decision no: 62).

Conflict of Interest: No conflict of interest was declared by the authors.

Author Contributions: Concept-DS; SupervisionMA; Materials-MQ; Data Collection and/or Processing-DS; Analysis and/ or Interpretation - DS, MA; Writing-DS.

Peer-review: Externally peer-reviewed

\section{REFERENCES}

1. Arul P, Shetty S, Masilamani S, Akshatha C., Naveen B. Evaluation of micronucleus in exfoliated buccal epithelial cells using liquid-based cytology preparation in petrol station workers. Indian Journal of Medical and Paediatric Oncology. 2017;38(3):273276.

2. Salem E, El-Garawani I, Allam H, El-Aal B., Hegazy M. Genotoxic effects of occupational exposure to benzene in gasoline station workers. Industrial Health. 2018;56(2):132-140.

3. International Agency for Research on Cancer. IARC monographs on the identification of carcinogenic hazards to humans. https:// monographs.iarc.fr. Accessed 4 Apr, 2019.

4. Celik A. Cytogenetic biomonitoring in petrol station attendants: micronucleus test in exfoliated buccal cells. Mutagenesis. 2003;18(5):-417 .421

5. Sridhar R, Badari R, Jesudass G, Prudhvi K. Micronuclear assay in petrol pump workers: A prospective observational study. Sch. Acad. J. Biosci. 2017;5(8):.555560

6. Hidayat H, Ismael M, Hasan H. Cytogenetic analysis of peripheral blood lymphocytes of workers occupationally exposed to benzene in a fuel station in Erbil City- Iraq. Science Journal of University of Zakho. 2016;4(1):.62-56

7. Kashyap B, Reddy P. Micronuclei assay of exfoliated oral buccal cells: Means to assess the nuclear abnormalities in different diseases. J Can Res Ther. 2012;8:.191-184

8. Kirkeleit J, Riise T, Bråtveit M, Moen B. Increased risk of acute myelogenous leukemia and multiple myeloma in a historical cohort of upstream petroleum workers exposed to crude oil. Cancer Causes \& Control. 2017;19(1):1323.

9. Singaraju S, Wanjari S, Singaraju M, Parwani R. Cytogenetic biomonitoring in petrol station attendants: A micronucleus study. Journal of Cytology. 2012;29(1):1-5.

10. Pranjić N, Mujagić H, Nurkić M, Karamehić J., Pavlović S. Assessment of health effects in workers at gasoline station. Bosnian Journal of Basic Medical Sciences. 2012;2(1-2):35-45.

11. Mrdjanović J, Šolajić S, Dimitrijević S, Đan I, Nikolić I, Jurišić V. Assessment of micronuclei and sister chromatid exchange frequency in the petroleum industry workers in province of Vojvodina, Republic of Serbia. Food and Chemical Toxicology. 2014;69:63-68. 
12. Tolbert P, Shy C, Allen J. Micronuclei and Other Nuclear Anomalies in Buccal Smears: A Field Test in Snuff Users. American Journal of Epidemiology. 1991;134(8):840-850.

13. Khisroon M, Gul A, Khan A, Ali N, Zaidi F, Rasheed S. Comet assay based DNA evaluation of fuel filling stations and automobile workshops workers from Khyber Pakhtunkhwa province, Pakistan. Journal of Occupational Medicine and Toxicology. 2015;10(1):1-6.

14. Shaikh A, Barot D, Chandel D. Genotoxic Effects of exposure to gasoline fumes on petrol pump workers. The International Journal of Occupational and Environmental Medicine. 2018;9 (2):79-87.

15. Uppala D, Peela P, Majumdar S, Tadakamadla M, Anand G. Evaluation and comparison of micronuclei from intraoral smears of petrol pump attendants and squamous cell carcinoma patients. Oral Maxillofac Pathol J. 2015;6 (1):550-555.

16. Benites C, Amado L, Vianna R, Martino-Roth M. Micronucleus test on gas station attendants. Genet Mol Res. 2006;5:45-54.

17. Kopjar N, Kašuba V, Milić M, Rozgaj R, Želježić D, Gajski G. Normal and cut-off values of the cytokinesis-block micronucleus assay on peripheral blood lymphocytes in the croatian general population. Archives of Industrial Hygiene and Toxicology. 2010;61(2):219-234.

18. Keretetse G, Laubscher P, Du-Plessis J, Pretorius $\mathrm{P}$, Westhuizen $\mathrm{F}$. DNA damage and repair detected by the comet assay in lymphocytes of african petrol attendants: a pilot study. Ann Occup Hyg. 2008;52:653-662. 
Table 1. Demographic characteristics of participants.

\begin{tabular}{|l|c|c|}
\hline & Cases & Controls \\
\hline Participants & 25 & 25 \\
\hline Age (Mean \pm St) & $28.3 \pm 7$ & $28.3 \pm 7$ \\
\hline Duration of work (Years) & $4.1 \pm 8$ & - \\
\hline The daily shift (hours) & $75 \pm 0$. & - \\
\hline
\end{tabular}




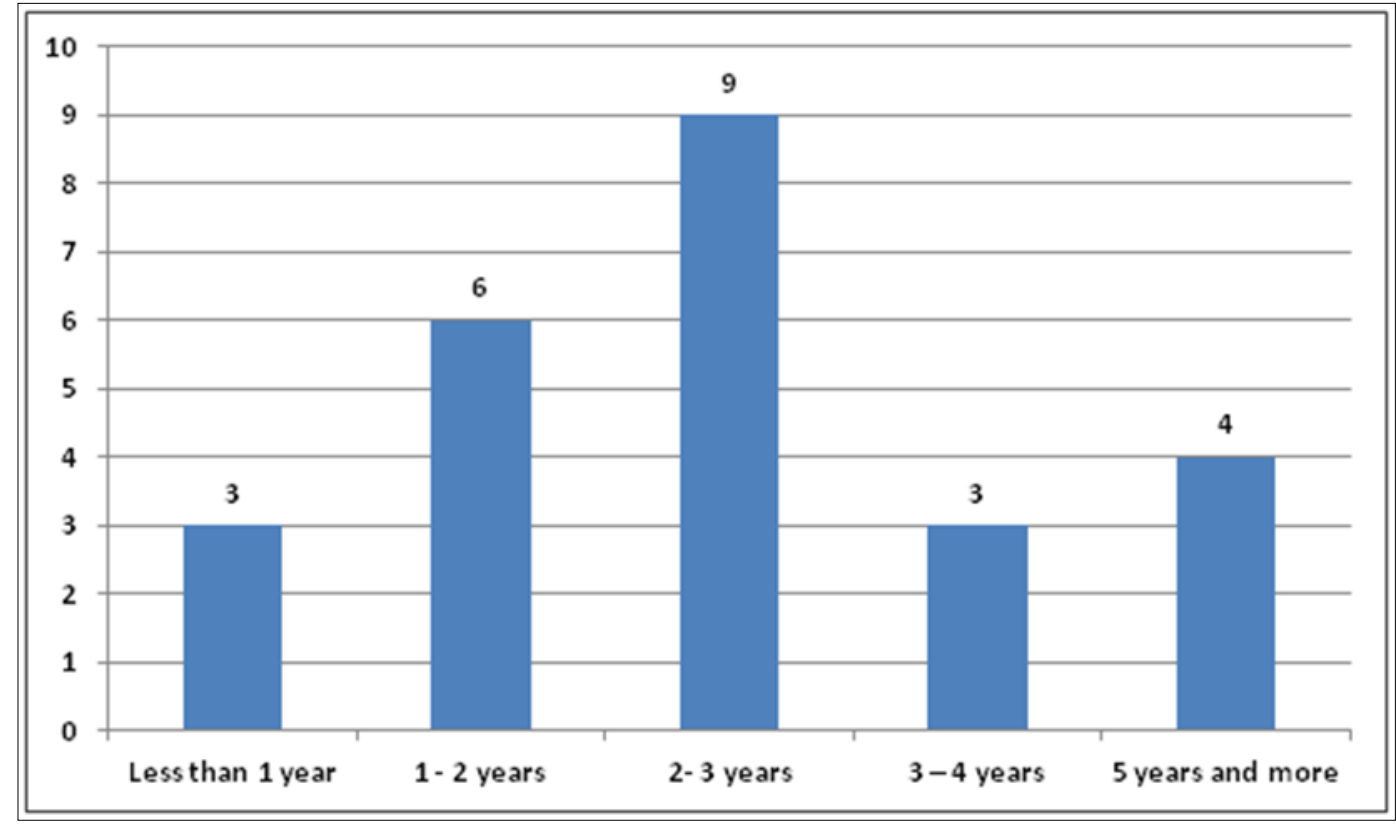

Figure 1. The duration of working in petrol stations. 


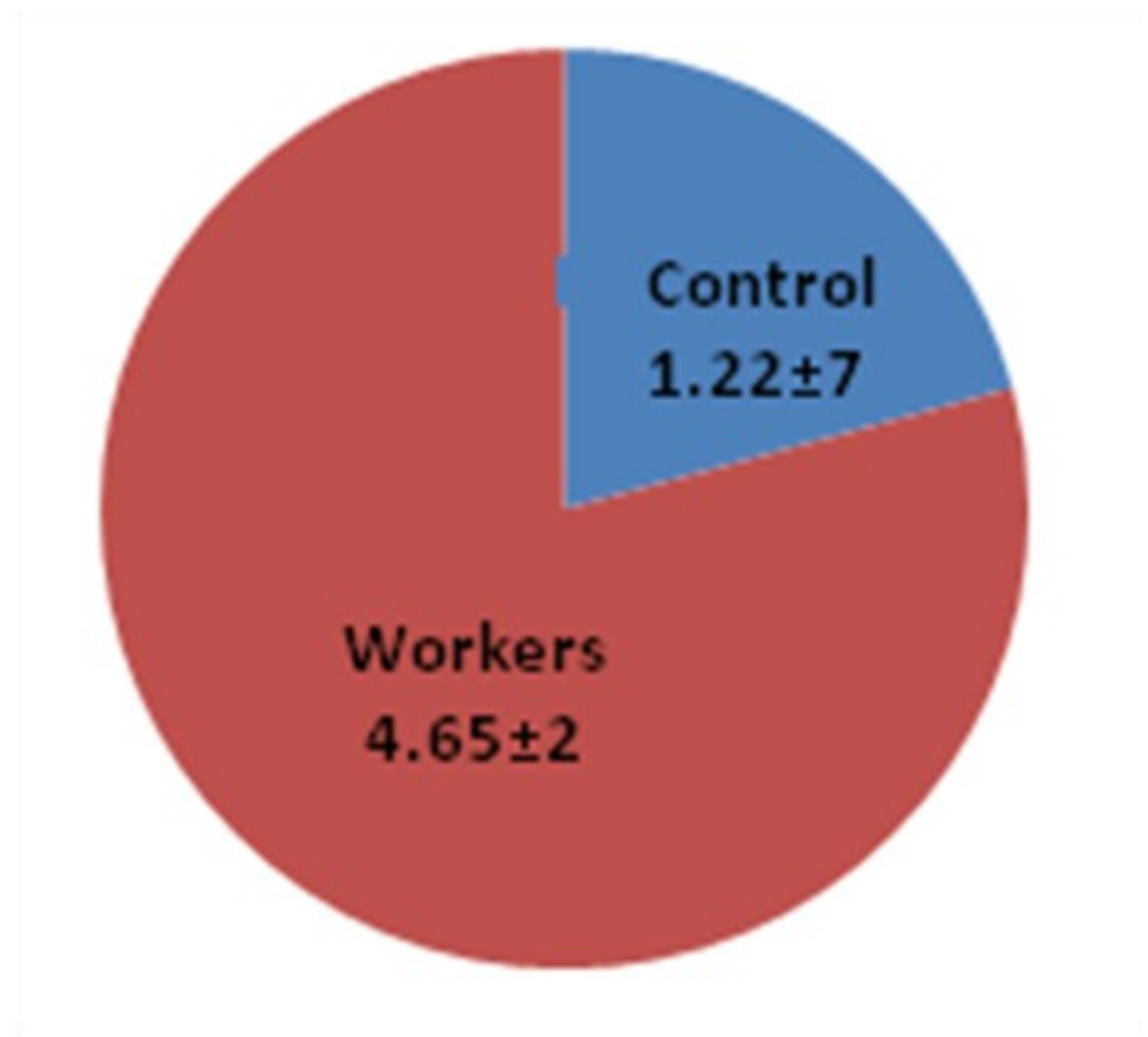

Figure 2. The mean frequency of micronuclei in exfoliated buccal epithelial cells of petrol station workers and controls. 

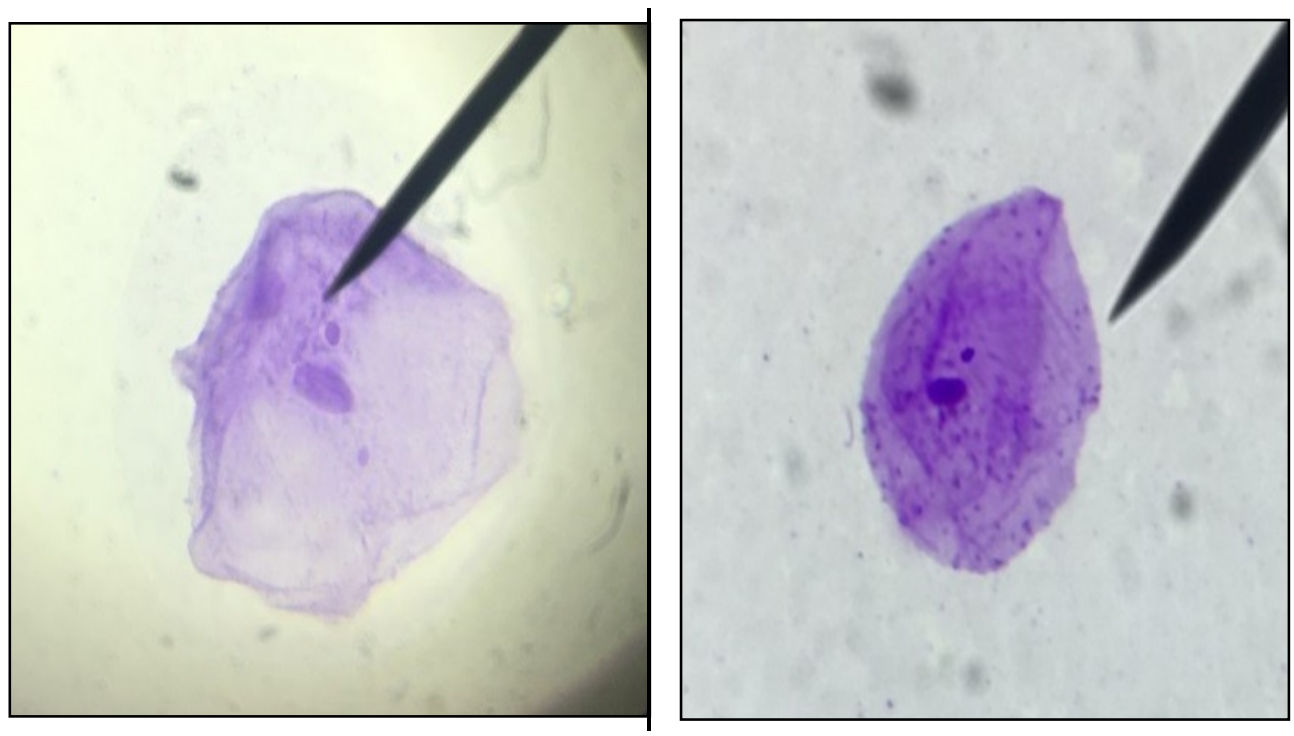

Figure 3. Cytosmears showing exfoliated buccal epithelial cells with micronucleus stained with Giemsa Stain x1000. 